Justyna Czerniak-Swędzioł (1) https://orcid.org/0000-0002-1524-2307

Uniwersytet Jagielloński w Krakowie

Błażej Mądrzycki ำ https://orcid.org/0000-0001-9165-6168

Uniwersytet Śląski w Katowicach

\title{
UNIWERSALIZM PRAWA PRACY ŚRODKIEM PRZECIWDZIAŁANIA WYKLUCZENIU SPOŁECZNEMU NIE TYLKO W DOBIE COVID-19
}

\author{
Abstract \\ Universalism of labour law a measure against social exclusion \\ not only in the COVID-19 era
}

The aim of the study is to show the essence of labour law through the prism of its characteristic structures and goals. Work is one of the most important values in human life, both in the context of securing living and personal conditions. While working, one acquires additional competencies and skills, which transfer into personal development. On the other hand, unemployment has negative living and social effects. For these reasons, it is necessary to show the tools of labour law that prevent broadly understood social exclusion. Their importance becomes more evident in times of crisis, when employees are affected by its effects. Therefore, the crisis caused by the COVID-19 pandemic is an important background for the ongoing considerations.

Słowa kluczowe: uniwersalizm prawa pracy, funkcja ochronna prawa pracy, wykluczenie społeczne, ubezpieczenia społeczne, zatrudnienie cywilnoprawne

Keywords: universalism of labour law, protective function of labour law, social exclusion, social security, civil law employment

ASJC: 3308, JEL: K31

\section{Wprowadzenie}

Aby można było ujmować prawo pracy jako środek zapobiegający wykluczeniu społecznemu, czynione rozważania należy rozpocząć od sposobu pojmowania przez Autorów „wykluczenia społecznego". 
Z perspektywy prowadzonych rozważań za społecznie wykluczoną uznaje się osobę nieposiadającą zasobów wystarczających do tego, aby w pełni uczestniczyć w życiu społecznym (Golinowska 2002, s. 14). Upraszczając sposób pojmowania wykluczenia, Autorzy przyjmują, że brak zatrudnienia, dostępu do swobodnie wybranej pracy czy też prawa do świadczeń to przyczyny wykluczenia.

Praca sama w sobie (jej dostępność, możliwość podjęcia, gratyfikacja za pracę) jest dobrem określonego rodzaju, z którego można dekodować określonego rodzaju wartości. Praca, czyli aktywność zawodowa, przekłada się na wiele czynników, w tym na rozwój osobisty prowadzący w dalszej konsekwencji do rozwoju społeczeństwa i stanu jego świadomości (Czerniak-Swędzioł, Mądrzycki 2019, s. 303 i n.). Poza wartościami niematerialnymi, odnosząc się do pracy ludzkiej, nie można zapominać o jej zarobkowym charakterze. Stąd też praca to także środek i narzędzie do zaspokajania bardziej lub mniej podstawowych potrzeb ludzi. Ujmując pracę w ten sposób, należy zgodzić się z wyrażonym w literaturze stanowiskiem, że:

(...) poczucie stabilizacji pracy jest jedną z najbardziej elementarnych potrzeb ludzkich, zaś jej brak stwarza poważne zagrożenia materialne i psychiczne dla pracowników i ich rodzin pozbawionych częściowo lub całkowicie możliwości zarobkowania i zaspokajania potrzeb (Masewicz, Kasprowicz 2015, s. 373).

O ile zatem praca powinna być postrzegana jako wartość dająca poczucie stabilizacji i bezpieczeństwa, o tyle jej brak lub zatrudnienie w warunkach niekorzystnych w zasadzie uniemożliwia zaspokajanie potrzeb.

Sam fakt podjęcia działań zarobkowych w pewnych okolicznościach może niewystarczająco chronić jednostki przed ryzykiem wykluczenia. W polskim systemie prawnym praca co do zasady podlega uregulowaniom przepisów prawa pracy. Prawo pracy jako samodzielna gałąź wyrosło na pracy ludzkiej (Szubert 1980, s. 17-42). Z całym wachlarzem obowiązujących konstrukcji dziedzina ta dba (przynajmniej z założenia), aby aktywność zawodowa obywateli pracowników odbywała się z poszanowaniem nie tylko pewnych standardów, gwarancji, ale także obowiązków, których nadrzędnym celem jest ochrona interesów obu stron stosunku pracy, a zatem pracowników i pracodawców. Jednakże na przestrzeni ostatnich lat coraz częściej w obrocie można spotkać się z praktyką zatrudnienia niepracowniczego - cywilnoprawnego. Mając świadomość skutków wynikających z zatrudnienia pracowniczego i niepracowniczego (cywilnego), stan swoistej powszechności stosowania zatrudnienia cywilnego rodzi uzasadnione obawy wykluczenia społecznego osób w ten sposób zatrudnionych. Taki stan, w dobie globalizacji i częstej konieczności skonfrontowania sytuacji jednostki ze zorganizowaną i fachową strukturą zatrudniającego, może prowadzić do uzasadnionych obaw i niepokojów społecznych. Szczególnie aktualna sytuacja, związana z epidemią COVID-19, obnażyła całkowicie „atrakcyjność” zatrudnienia cywilnoprawnego, ukazując jego niestabilność, słabość, a przede wszystkim całkowity brak elementarnej ochrony przed wykluczeniem zatrudnionego. $Z$ dnia na dzień zatrudnieni na innej podstawie niż stosunek pracy utracili nie tylko źródło dochodu, ale 
też - co najważniejsze - możliwość wsparcia socjalnego. Jednocześnie zaproponowane przez ustawodawcę rozwiązania w postaci ustawy antykryzysowej (Dz.U. 2020, poz. 568, dalej: „ustawa antykryzysowa”, „ustawa tarczowa”, „tarcza”) starają się - względem nie tylko pracowników, lecz również niepracowników - stworzyć gwarancje dotychczas im nieznane. Przede wszystkim są to rozwiązania, które mają zapobiec wykluczeniu, choć już teraz powstaje pytanie, czy służą one ochronie pracownika (wymiar podmiotowy), czy być może jedynie ochronie miejsca pracy (wymiar przedmiotowy).

Celem niniejszego opracowania jest ukazanie, jak poszczególne regulacje towarzyszące zatrudnieniu pracowniczemu faktycznie zabezpieczają obywateli przed ryzykiem wykluczenia i aktualnie wykorzystywane są również względem niepracowników. Tym samym Autorzy podkreślają, jakie konsekwencje pociąga za sobą upowszechnienie zatrudnienia niepracowniczego, co niezwykle widoczne pozostaje w obliczu trwającego zagrożenia epidemiologicznego, którego skutki ekonomiczne oraz społeczne odbiły się przede wszystkim na rynku pracy i prekariuszach, czyli grupie zatrudnionych w ramach elastycznych form zatrudnienia.

\section{Szerokie pojęcie pracownika sposobem na wykluczenie?}

W myśl art. 15g ust. 4 ustawy antykryzysowej pracownikiem jest osoba fizyczna, która zgodnie $\mathrm{z}$ przepisami polskiego prawa pozostaje $\mathrm{z}$ pracodawcą $\mathrm{w}$ stosunku pracy. Nie ulega zatem wątpliwości, że wskazana ustawa obejmuje zatrudnienie pracownicze oparte na jednej z podstaw, o których mowa w art. 2 ustawy z dnia 26 czerwca 1974 roku Kodeks pracy (Dz.U. 2020, poz. 1320 tekst jedn. z dnia 30 lipca 2020 roku, dalej: „Kodeks pracy”, „k.p.”), pomimo że do kodeksu nie odnosi się wprost (Baran 2020). Jak podkreśla się w literaturze przedmiotu, definicja pracownika ma charakter uniwersalny dla całego systemu polskiego prawa pracy (Baran 2018, s. 36) i brak odwołania się w art. 2 k.p. do terminu osoby fizycznej (tak jak czyni to ustawodawca w art. 15g ust. 4 tarczy) jako pracownika nie budzi żadnych wątpliwości, a to z uwagi na wymóg osobistego świadczenia pracy.

$\mathrm{Na}$ gruncie regulacji antykryzysowej (tarczowej) ustawodawca znacznie rozszerza definicję pracownika również względem osób zatrudnionych na podstawie umowy o pracę nakładczą, umowy zlecenia, innej umowy o świadczenie usług, do której zgodnie z ustawą z dnia 23 kwietnia 1964 roku - Kodeks cywilny (Dz.U. 2020, poz. 1740 tekst jedn. z dnia 8 października 2020 roku, dalej: „Kodeks cywilny”) stosuje się przepisy dotyczące zlecenia, albo względem osoby, która wykonuje pracę zarobkową na podstawie innej niż stosunek pracy na rzecz pracodawcy będącego rolniczą spółdzielnią produkcyjną lub inną spółdzielnią zajmującą się produkcją rolną, jeżeli z tego tytułu podlega obowiązkowi ubezpieczeń: emerytalnemu i rentowemu. Ustawodawca wyłączył z definicji pracownika pomoc domową zatrudnianą przez osobę fizyczną.

To wyliczenie ma charakter taksatywny i obejmuje wybrane rodzaje niepracowniczych stosunków zatrudnienia o charakterze cywilnoprawnym. Wydaje się przy tym, że 
ustawodawca, dokonując wyboru akurat tych tytułów zatrudnienia, posłużył się kryterium ich swoistego pokrewieństwa do statusu zatrudnienia pracowniczego, a także kryterium powszechności oraz popularności ich występowania w obrocie gospodarczym (Baran 2020).

Ustawa tarczowa nie wprowadziła do szerokiej definicji pracownika osób zatrudnionych na podstawie umowy o dzieło, umowy agencyjnej, wolontariuszy czy też samozatrudnionych. Stąd pojęcie pracownika na gruncie ustawy tarczowej pozostaje jednak węższe od pojęcia „osoby wykonującej pracę zarobkową” zdefiniowanej w przepisach ustawy z dnia 23 maja 1991 roku o związkach zawodowych (Dz.U. 2019, poz. 263 tekst jedn. $z$ dnia 12 lutego 2019 roku).

Mając na względzie rzecz jasna wyjątkowość zaistniałej sytuacji epidemiologicznej i zaproponowanych w związku z nią przez ustawodawcę jedynie czasowych rozwiązań, nie można oprzeć się wrażeniu, że dwoistość charakteru zatrudnionych (pracowników i niepracowników) została sprowadzona do jednego mianownika i objęta jednym wspólnym celem, to jest ochroną przed wykluczeniem bez względu na treść stosunku obligacyjnego stanowiącego podstawę zatrudnienia. Należy przy tym podkreślić, że złożenie przez podmiot zatrudniający stosownych oświadczeń - wymaganych na gruncie ustawy tarczowej w celu przyznania pomocy - nie powoduje wprost modyfikacji treści konkretnego stosunku prawnego statuującego dane zatrudnienie, a jest zobowiązaniem podmiotu zatrudniającego do utrzymania zatrudnienia, które determinuje to, czy uzyskana pomoc będzie miała charakter bezzwrotny.

Ustawa z dnia 13 października 1998 roku o systemie ubezpieczeń społecznych (Dz.U. 2020, poz. 266 tekst jedn. ze zm.) również posługuje się pojęciem pracownika $\mathrm{w}$ różnych kontekstach. Traktowanie stosunku pracy jako tytułu do ubezpieczeń społecznych jest pewnym skrótem myślowym, bo w art. 6 tej ustawy wskazano jedynie kategorie osób, które podlegają ubezpieczeniu, a nie stosunki prawne (Roszewska 2020, s. 11). Bez wątpienia stosunek pracy stanowi podstawę objęcia pracownika ubezpieczeniami (obowiązkowymi), ale tytułem do ubezpieczeń społecznych pozostają także: zatrudnienie (cywilnoprawne), działalność lub inna sytuacja, której wystąpienie rodzi obowiązek lub uprawnienie do objęcia ubezpieczeniami na zasadzie dobrowolności. Ustawa o systemie ubezpieczeń społecznych (w art. 8) odnosi się do pracowników w dwojaki sposób. Po pierwsze posługuje się pojęciem pracownika jako osoby pozostającej w stosunku pracy, pomimo że nie odwołuje się wprost do przepisów Kodeksu pracy. Po drugie za pracownika uważa także osobę wykonującą pracę na podstawie umowy agencyjnej, umowy zlecenia lub innej umowy o świadczenie usług, do której zgodnie z Kodeksem cywilnym stosuje się przepisy dotyczące umowy zlecenia albo umowy o dzieło, jeżeli umowę taką zawarła z pracodawcą, z którym pozostaje w stosunku pracy, lub jeżeli w ramach takiej umowy wykonuje pracę na rzecz pracodawcy, z którym pozostaje w stosunku pracy. Jak słusznie zauważa Roszewska (2020, s. 23), pojęcie „pracownik" towarzyszy ubezpieczeniom społecznym naturalnie od samego początku i w celu ochrony tej grupy osób doszło do powołania tych ubezpieczeń i w ujęciu teoretycznym traktowane były przez dłuższy czas jako część prawa pracy. $\mathrm{W}$ regulacjach prawa 
ubezpieczeń społecznych na pierwszy plan zdecydowanie wysuwają się cele i funkcje tej dziedziny prawa, czyli ochrona skutków ryzyk socjalnych osób zatrudnionych na podstawie wadliwych stosunków pracy, a także przeciwdziałanie fluktuacji w zatrudnieniu (Roszewska 2020).

Jak widać w tym zestawieniu regulacji ustawy tarczowej i ustawy ubezpieczeniowej, definiowanie pojęcia „pracownik” wykracza znacznie poza standardy kodeksowe. Zdaniem Autorów świadczy to o potrzebie ukształtowania definicji osoby zatrudnionej w taki sposób, aby mogła ona być w pełni chroniona przed wykluczeniem, a jednocześnie aby na podmiot zatrudniający nie zostały przeniesione wszelkie obciążenia socjalne i związane z tym ryzyka. Dlatego tak istotne jest podjęcie próby usystematyzowania pojęć z zakresu prawa pracy i ich znaczenia na gruncie innych ustaw.

\section{Obowiązkowe ubezpieczenia społeczne jako forma zapobiegania wykluczeniu?}

Jednym z najbardziej wyraźnych i znanych narzędzi, które można sprowadzić do kategorii swoistej gwarancji zapobiegjącej wykluczeniu społecznemu (zabezpieczeniu obywateli przed ubóstwem), jest ubezpieczenie społeczne. Intencją ubezpieczenia jest zapewnienie ochrony podmiotów w okolicznościach, gdy podlegają czasowej niezdolności do pracy ze względu na stan zdrowia lub realizują obowiązki rodzicielskie (ubezpieczenie chorobowe i wypadkowe), gdy podlegają trwałej niezdolności do pracy (ubezpieczenie rentowe) lub osiągnęli wiek uprawniający do powstrzymania się od aktywności zawodowej (ubezpieczenie emerytalne).

Obowiązek podlegania ubezpieczeniu społecznemu jest immanentnie wpisany w zatrudnienie pracownicze. I o ile na gruncie aktualnego porządku prawnego praca nie jest obowiązkowa, o tyle podjęcie pracowniczego zatrudnienia wiąże się z obowiązkiem podlegania pod ubezpieczenie społeczne. Podmiot o statusie pracownika obligatoryjnie objęty jest funduszem emerytalnym, rentowym, chorobowym i wypadkowym.

Inaczej rysuje się natomiast sytuacja w przypadku umów cywilnoprawnych. W ograniczonym wymiarze ubezpieczeniu społecznemu podlegają umowy zlecenia i umowy o świadczenie usług, do których odpowiednie zastosowanie mają przepisy o zleceniu. Przyjmując założenie, że podmiot nie jest rencistą ani emerytem i korzysta tylko z jednej podstawy zatrudnienia - umowy zlecenia lub świadczenia - jego sytuacja zrównana jest $\mathrm{z}$ sytuacją pracownika. W podobny sposób kształtuje się obowiązek ubezpieczenia wypadkowego, bowiem - analogicznie jak w przypadku umów o pracę - jest to ubezpieczenie obowiązkowe, opłacane przez pracodawcę lub na gruncie cywilnoprawnym na przykład przez dającego zlecenie.

Nieco odmiennie przedstawia się sytuacja związana z ubezpieczeniem chorobowym. Ubezpieczenie chorobowe, jak już zasygnalizowano, w przypadku pracowniczego zatrudnienia ma charakter ubezpieczenia obowiązkowego, koszt z nim związany pokrywa pracownik za pośrednictwem pracodawcy. Rodzaje świadczeń mieszczących się w ramach 
funduszu chorobowego odgrywają niemałe znaczenie w procesie wykonywania pracy. Świadczenia dostępne w ramach tego funduszu przysługują między innymi w sytuacji niezdolności do wykonywania pracy ze względu na stan zdrowia (zasiłek chorobowy) lub w przypadku powstrzymania się od pracy z powodu realizowania obowiązków rodzicielskich (zasiłek macierzyński) lub sprawowania opieki (zasiłek opiekuńczy). Można zatem przyjąć, że ubezpieczenie chorobowe jest swoistą gwarancją zapewniającą ubezpieczonemu dostęp do niezbędnych środków w okolicznościach powstrzymywania się od aktywności zawodowej. Jak podkreślono w orzecznictwie, ratio legis ustawy z dnia 25 czerwca 1999 roku o świadczeniach pieniężnych z ubezpieczenia społecznego w razie choroby i macierzyństwa (Dz.U. 2020, poz. 870 tekst jedn. z dnia 15 maja 2020 roku, dalej: „ustawa o świadczeniach pieniężnych z ubezpieczenia społecznego w razie choroby i macierzyństwa”, „u.o.ś.p.") jest zapewnienie ubezpieczonym godziwego zabezpieczenia w razie choroby i macierzyństwa (wyrok Sądu Apelacyjnego w Lublinie z dnia 27 kwietnia 2016 roku, III AUa 1023/15, Legalis nr 1460532).

Mając na uwadze przeznaczenie tego typu ubezpieczenia, można byłoby przyjąć, że ustawodawca realizuje politykę społeczną, dopuszczając możliwość objęcia ubezpieczeniem chorobowym osób zatrudnionych w warunkach cywilnoprawnych. Pomimo że ustawodawca dopuszcza takową ochronę, to warunki korzystania $\mathrm{z}$ tego ubezpieczenia przez zatrudnionych niebędących pracownikami są odmienne niż te obowiązujące pracowników.

Pierwszą zasadniczą kwestią jest to, że ubezpieczony niebędący pracownikiem i niezdolny do pracy nabędzie uprawnienie do świadczeń dopiero po upływie tak zwanego okresu wyczekiwania, to jest dziewięćdziesięciu dni, a więc okresu dłuższego, niż ustawodawca przewidział dla osób będących pracownikami ${ }^{1}$. Wydłużenie tego okresu dla ubezpieczonych niepracowników jest o tyle niekorzystne, że prawo do zasiłku chorobowego można nabyć dopiero po spełnieniu okresu wyczekiwania i że do tego okresu nie można wliczyć okresu niezdolności powstałej przed upływem trzydziestu dni opłacania składki (okres bez prawa do zasiłku chorobowego, za który nie jest odprowadzana składka na ubezpieczenie chorobowe) - to ubezpieczony, który przed upływem okresu wyczekiwania stanie się niezdolny do pracy, nie nabywa prawa do zasiłku chorobowego (Rzetecka-Gil 2009; wyrok Sądu Apelacyjnego w Poznaniu z dnia 14 maja 2015 roku, III AUa 1394/14, LEX nr 1798650). Konsekwencją obowiązującej regulacji jest ryzyko (pomimo odprowadzenia składki) braku świadczeń, gdy ubezpieczony nie przetrwa długiego, bo aż dziewięćdziesięciodniowego okresu wyczekiwania. W uzasadnieniu do projektu ustawy o świadczeniach pieniężnych z ubezpieczenia społecznego w razie choroby i macierzyństwa (druk sejmowy nr 840 ) projektodawca wskazał, że:

(...) zachowanie i stosowanie okresów wyczekiwania wydaje się niezbędne, aby uniknąć sytuacji, w których osoby ubezpieczone (w szczególności osoby ubezpieczone dobrowolnie), nabyły po

${ }^{1}$ Zgodnie z art. 4. ust. 1 u.o.ś.p.: „Ubezpieczony nabywa prawo do zasiłku chorobowego: 1. po upływie 30 dni nieprzerwanego ubezpieczenia chorobowego - jeżeli podlega obowiązkowo temu ubezpieczeniu”. 
krótkim, niekiedy kilkudniowym okresie opłacania niewielkich składek (...) prawo do świadczeń przez okres kilku, a niekiedy nawet ponad 20 miesięcy.

Zasadność ustalenia przez ustawodawcę różnych okresów wyczekiwania dla obowiązkowego i dobrowolnego ubezpieczenia chorobowego była przedmiotem zainteresowania Trybunału Konstytucyjnego. W wyroku z dnia 16 listopada 2010 roku (P 86/2008, LEX nr 613882) Trybunał uznał, że:

Art. 4 ust. 1 pkt 2 ustawy z dnia 25 czerwca 1999 r. o świadczeniach pieniężnych z ubezpieczenia społecznego w razie choroby i macierzyństwa (Dz. U. z 2010 r. Nr 77, poz. 512), w brzmieniu obowiązującym do 31 grudnia 2008 r., w zakresie, w jakim dla osób prowadzących pozarolniczą działalność gospodarczą, podlegających dobrowolnie ubezpieczeniu chorobowemu, określa dłuższy niż dla osób podlegających obowiązkowo ubezpieczeniu chorobowemu okres nieprzerwanego ubezpieczenia chorobowego wymagany do nabycia prawa do zasiłku chorobowego, jest zgodny z art. 32 ust. 1 oraz art. 2 Konstytucji Rzeczypospolitej Polskiej.

Jakkolwiek obowiązująca regulacja jest zgodna z Konstytucją, to nie da się zaprzeczyć, że w obowiązującym kształcie niewystarczająco chroni zatrudnionych na podstawie umów cywilnoprawnych, co z kolei może przekładać się na ryzyko utraty środków niezbędnych do zaspokojenia podstawowych potrzeb. Dość kontrowersyjne jest także to, że zwolnienie $\mathrm{z}$ okresu wyczekiwania na podstawie stażu ubezpieczeniowego nie dotyczy ubezpieczonych dobrowolnie. W praktyce ubezpieczony dobrowolnie pracownik wykazujący się dziesięcioletnim stażem ubezpieczeniowym nie korzysta $\mathrm{z}$ takiego uprawnienia. O ile za wydłużeniem okresu wyczekiwania może stać argument prewencji przed próbą wyłudzenia świadczenia, o tyle trudno uzasadnić fakt podziału w przypadku długoletniego dobrowolnego opłacania składek (Jędrasik-Jankowska 2015, s. 82-83).

Kwestią, której nie można pominąć w czynionych rozważaniach, jest usprawiedliwiona nieobecność w pracy wywołana niezdolnością do pracy. Konstrukcje tego typu, charakterystyczne dla pracowniczego zatrudnienia, co do zasady są obce dla zatrudnienia cywilnego. Oznacza to, że nawet zatrudniony, który uzyska prawo do świadczenia z ubezpieczenia chorobowego, powstrzymując się od wykonywania zlecenia lub usługi, ryzykuje wypowiedzeniem tej umowy przez zatrudniającego. W takich okolicznościach słuszny byłby argument, że zatrudniony może zabezpieczyć się $\mathrm{w}$ umowie (dokonując w tym celu stosowanych uzgodnień) przed jej wypowiedzeniem w czasie, gdy pozostaje na zwolnieniu lekarskim. Warto jednak zwrócić uwagę, że taki postulat może nie spotkać się z aprobatą zleceniodawcy. Mogącym budzić niechęć skutkiem takiego postanowienia umownego jest ryzyko wydłużenia czasu wykonania zlecenia lub usługi. Ponadto wzbogacanie umów cywilnoprawnych o postanowienia charakterystyczne dla pracowniczego zatrudnienia może rodzić obawy procesu o ustalenie istnienia stosunku pracy (wyrok Sądu Najwyższego - Izba Pracy, Ubezpieczeń Społecznych i Spraw Publicznych z dnia 28 marca 2017 roku, 
II PK 15/16, Legalis nr 1617915), tym bardziej że z takowym roszczeniem może wystąpić inspektor pracy².

Kolejna różnica wymagająca omówienia pojawia się na tle pewnych uprawnień związanych $\mathrm{z}$ rodzicielstwem. Zgodnie $\mathrm{z}$ ustawą o świadczeniach pieniężnych $\mathrm{z}$ ubezpieczenia społecznego $w$ razie choroby i macierzyństwa uprawnienie do zasiłku macierzyńskiego przysługuje między innymi w przypadku urodzenia dziecka w okresie ubezpieczenia chorobowego (por. art. 29 u.o.ś.p.). Zakres ochrony ubezpieczeniowej i w tym przypadku nie jest korzystny dla osoby zatrudnionej w formie cywilnoprawnej. Należy zauważyć, że w świetle obowiązującego i przytoczonego powyżej przepisu zasiłek macierzyński przysługuje wyłącznie ubezpieczonej, która w chwili porodu jest objęta ubezpieczeniem. Kodeks pracy obejmuje szczególną ochroną trwałości zatrudnienia kobiety w ciąży, która nie jest realizowana względem kobiety w ciąży zatrudnionej na innej podstawie. Ponadto w warunkach wskazanych w art. 177 k.p. umowy na okres próbny i na czas określony przedłużają się do dnia porodu. W konsekwencji jeżeli początkowo umowa o pracę została zawarta na czas, który upłynąłby przed porodem, z mocy prawa ulegnie ona przedłużeniu. Na skutek takich regulacji w chwili porodu kobieta korzysta z ubezpieczenia. Zupełnie inaczej kształtuje się sytuacja ubezpieczonej, jeżeli jej tytułem do ubezpieczenia jest umowa cywilna. Kobieta w ciąży zatrudniona na podstawie umowy cywilnej (pomimo dobrowolnego zgłoszenia do ubezpieczenia chorobowego) nie korzysta z ochrony trwałości zatrudnienia, co oznacza, że przed porodem podmiot zatrudniający ma uprawnienie do rozwiązania cywilnego kontraktu. W konsekwencji mimo przystąpienia do ubezpieczenia ubezpieczona nie nabędzie prawa do świadczeń, które utraci wraz z zakończeniem umowy cywilnej. Co więcej, nawet gdyby ubezpieczona przed porodem przebywała na zwolnieniu lekarskim, to podmiot zatrudniający, inaczej niż w przypadku umowy o pracę, ma prawo umowę wypowiedzieć, co w konsekwencji wykluczy ubezpieczoną z kręgu osób uprawnionych do zasiłku macierzyńskiego. Ustawodawca na gruncie Kodeksu cywilnego nie przewiduje także konstrukcji przedłużenia cywilnej umowy terminowej zawartej z kobietą w ciąży, do dnia porodu.

Pozostając $w$ tematyce uprawnień związanych $\mathrm{z}$ rodzicielstwem, należy również wskazać na regulację dotyczącą zasiłku opiekuńczego, który na gruncie przepisów ustawy tarczowej nabrał zupełnie nowego charakteru. Zasiłek opiekuńczy jest kolejnym obok zasiłku macierzyńskiego świadczeniem pieniężnym przysługującym ubezpieczonemu zwolnionemu od wykonywania pracy z powodu sprawowania osobistej opieki nad członkiem rodziny. Jest zatem świadczeniem realizującym funkcje prorodzinną oraz ochronną. Świadczenia pieniężne z ubezpieczenia społecznego w razie choroby i macierzyństwa, które obejmują między innymi zasiłek opiekuńczy, mają na celu pokrycie szkody spowodowanej zajściem danego rodzaju ryzyka, to jest określonej sytuacji życiowej,

2 Zgodnie z Postanowieniem Sądu Najwyższego z dnia 29 grudnia 1998 roku (I PKN 494/98, Legalis nr 44382): „Zgoda pracownika jest wymagana tylko na wstąpienie inspektora pracy do postępowania w sprawie o ustalenie istnienia stosunku pracy, nie zaś do wytoczenia powództwa przez inspektora na rzecz pracownika (art. 63[1] KPC)". 
z której wystąpieniem wiąże się opłacanie składki (wyrok Trybunału Konstytucyjnego z dnia 6 marca 2007 roku, P 45/06, OTK-A 2007, nr 3, poz. 22). W przypadku zasiłku opiekuńczego treścią ryzyka jest ochrona sytuacji polegających na zapewnieniu opieki dziecku lub innemu choremu członkowi rodziny (Jędrasik-Jankowska 2003, s. 33). Zasiłek opiekuńczy ma zatem na celu ochronę osoby ubezpieczonej przed utratą wynagrodzenia w przypadku konieczności osobistego sprawowania opieki nad zdrowym dzieckiem do ukończenia lat 8, a w określonych sytuacjach chorym dzieckiem w wieku do ukończenia 14 lat oraz innym chorym członkiem rodziny. Ryzykiem ubezpieczeniowym nie są w tym przypadku objęte sytuacje, gdy dojdzie do nieprzewidzianego zamknięcia żłobka, przedszkola lub szkoły, do których dziecko uczęszcza, a także w przypadku choroby niani, z którą rodzice mają zawartą umowę uaktywniającą (art. 50 ustawy z dnia 4 lutego 2011 roku o opiece nad dziećmi w wieku do lat 3, Dz.U. 2021, poz. 75 tekst jedn. z dnia 13 stycznia 2021 roku), lub dziennego opiekuna sprawujących opiekę nad dzieckiem, porodu lub choroby małżonka ubezpieczonego, stale opiekującego się dzieckiem, jeżeli poród lub choroba uniemożliwia temu małżonkowi sprawowanie opieki, oraz pobytu małżonka ubezpieczonego lub rodzica dziecka stale opiekujących się dzieckiem w szpitalu albo innym zakładzie leczniczym podmiotu leczniczego wykonującego działalność leczniczą w rodzaju stacjonarne i całodobowe świadczenia zdrowotne - gdy zdrowe dziecko ma więcej niż 8 lat. I dlatego też ustawodawca właśnie w ustawie antykryzysowej (art. 4) objął wymienione sytuacje ryzykiem ubezpieczeniowym, wprowadzając na czas zagrożenia epidemiologicznego możliwość skorzystania z tak zwanego dodatkowego zasiłku opiekuńczego, który ma charakter uzupełniający w stosunku do zasiłku opiekuńczego przysługującego na podstawie przepisów ubezpieczeniowych.

Zasiłek opiekuńczy jest wypłacany przez krótki czas lub jednorazowo jako jedno ze świadczeń wypłacanych z ubezpieczenia chorobowego i w całości finansowany z funduszu ubezpieczeń społecznych, nawet gdy wypłaca go pracodawca. Prawo do zasiłku opiekuńczego, w odróżnieniu od prawa do zasiłku chorobowego, przysługuje ubezpieczonym bez okresu wyczekiwania.

Podmiotem uprawnionym do otrzymania zasiłku opiekuńczego jest ubezpieczony zwolniony z wykonywania pracy z powodu konieczności osobistego sprawowania opieki. W obecnym stanie prawnym bez znaczenia pozostaje forma ubezpieczenia - rozumiana jako fakt obowiązkowego albo dobrowolnego podlegania ubezpieczeniu chorobowemu. W zakresie prawa do zasiłku a formy ubezpieczenia wypowiedział się Trybunał Konstytucyjny, który w wyroku z dnia 6 marca 2007 roku (P 46/06, OTK-A 2007, nr 3, poz. 22) wskazał, że art. 32 ust. 1 pkt 2 i 3 u.o.ś.p. w części, w której zawiera słowo „obowiązkowo", jest niezgodny z art. 2 i art. 32 ust. 1 Konstytucji Rzeczypospolitej Polskiej (Dz.U. 1997, nr 78, poz. 483 ze zm.). Oceniane przez Trybunał Konstytucyjny brzmienie przepisu przyznawało prawo do zasiłku opiekuńczego wyłączenie ubezpieczonym obowiązkowo i wskutek powołanego orzeczenia Trybunału ustawą z dnia 11 kwietnia 2008 roku o zmianie ustawy o świadczeniach pieniężnych z ubezpieczenia społecznego w razie choroby i macierzyństwa (Dz.U. 2008, nr 93, poz. 582) zasiłek opiekuńczy przysługuje także ubezpieczonym dobrowolnie. 
Konkludując, należy podkreślić, że w sferze ubezpieczeń społecznych jedynie zatrudnienie pracownicze gwarantuje bardzo szeroką ochronę przed wykluczeniem właśnie z uwagi na obligatoryjność objęcia pracownika ubezpieczeniem społecznym.

Pomimo dopuszczalności przez ustawodawcę dobrowolnego przystąpienia do ubezpieczenia chorobowego przez zatrudnionych na podstawie umów cywilnoprawnych skorzystanie ze świadczeń przewidzianych w ramach tego ubezpieczenia może okazać się iluzoryczne. W konsekwencji podmiot opłacający składki może z nich nigdy nie skorzystać, co w zasadzie na gruncie pracowniczego zatrudnienia nie może mieć miejsca. Finalnie osoba dobrowolnie zgłaszająca się do ubezpieczenia może zostać pozbawiona środków do życia. W takiej sytuacji pozostaje konieczność ubiegania się o świadczenia z pomocy społecznej. Oznacza to, że przyjęta przez ustawodawcę konstrukcja jest pewnym zaprzeczeniem istoty ubezpieczenia społecznego jako fundamentu solidaryzmu społecznego (ZUS 2017).

Niejako na marginesie warto podkreślić, że przyjmując tego typu postanowienie, ustawodawca w zasadzie przesuwa ryzyko zadbania o własny interes wyłącznie na zatrudnionego. O ile w zatrudnieniu pracowniczym w naturalny sposób pracownik może skorzystać z przysługujących mu uprawnień ubezpieczeniowych, o tyle zatrudniony cywilnoprawnie, pomimo odprowadzenia składki w takim samym procencie jak pracownik, faktycznie może nie mieć okazji do skorzystania $\mathrm{z}$ tego ubezpieczenia. W takich okolicznościach można postawić retoryczne pytanie o cel dobrowolnego ubezpieczenia chorobowego w kontekście braku ochrony dla kobiet w ciąży zatrudnionych w formie cywilnoprawnej.

\section{Ochronna funkcja prawa pracy - zabezpieczenie przed wykluczeniem społecznym}

Bez wątpienia wartością prawa pracy, z której można wyprowadzać narzędzie zapobiegające wykluczeniu społecznemu, będzie ochrona pracownika gwarantowana na gruncie pracowniczego zatrudnienia. Pomijając wszelkie aspekty ochronne towarzyszące macierzyństwu (rodzicielstwu), prawo pracy chroni zatrudnionych także w innych okolicznościach.

Jednym z wyraźnych przejawów ochrony pracowników przed wykluczeniem społecznym w przyjętym rozumieniu jest przewidziana w art. 39 k.p. ochrona pracowników znajdujących się w wieku przedemerytalnym. Ten wątek doskonale wpisuje się w treść niniejszego opracowania przede wszystkim przez wzgląd na stosunkowo nowe, ale odmienne od dotychczasowego orzecznictwo dotyczące zakresu ochrony przedemerytalnej. W wyroku z dnia 18 grudnia 2014 roku (II PK 50/14, Legalis nr 1185774) Sąd Najwyższy przyjął stanowisko, zgodnie z którym prawidłową wykładnią art. 39 k.p. jest wykładnia prowadząca do stwierdzenia, że ochrona zatrudnienia, o której mowa w tym przepisie, zakazuje wypowiedzenia umowy o pracę na czas określony zawartej na czas upływający przed osiągnięciem przez pracownika wieku emerytalnego. Stanowisko 
Sądu Najwyższego zaprezentowane w przywołanym judykacie przełamuje dotychczasową linię orzecznictwa poświęconą temu zagadnieniu. Dotychczas Sąd Najwyższy stał na stanowisku (wyrok z dnia 27 lipca 2011 roku, II PK 20/11, LEX nr 1026630), że:

(...) przewidziany w art. 39 K.p. zakaz wcześniejszego wypowiedzenia umowy o pracę nie dotyczy umowy o pracę zawartej na czas określony, która uległaby rozwiązaniu z upływem okresu jej trwania przed osiągnięciem przez pracownika wieku emerytalnego umożliwiającego mu uzyskanie prawa do emerytury.

Niewątpliwie aktualnie prezentowane stanowisko Sądu Najwyższego godzi się z teorią prawa pracy jako narzędzia zapobiegającego wykluczeniu. Przyjęta interpretacja, chroniąc pracownika przed wypowiedzeniem umowy, gwarantuje mu prawo do pracy. W takich okolicznościach można wywieść, że prawo pracy przez swoistą gwarancję zatrudnienia dla pracowników, którzy mogą - czego nie należy uznawać za regułę - mieć problem ze znalezieniem pracy ze względu na wiek, chroni pracownika przed ryzykiem wykluczenia społecznego w znaczeniu przyjętym w niniejszej pracy.

Rozwiązania tarczowe, które wprawdzie nie nałożyły na podmioty zatrudniające ustawowego zakazu rozwiązywania umów, a jedynie zobowiązanie do niewypowiadania umowy przez okres pobierania świadczeń, jak również po zakończeniu tego okresu przez okres kolejnych miesięcy odpowiadający długością liczbie miesięcy pobierania świadczeń, bez wątpienia stwarzają ochronę przed utratą pracy. Pomimo że ochrona ta nie ma wymiaru podmiotowego, to nawet w ujęciu przedmiotowym, czyli chroniąc jedynie miejsce pracy, a nie samych pracowników, zapobiega wykluczeniu przynajmniej na czas zagrożenia wirusem COVID-19.

\section{Wnioski końcowe}

Jak wynika z przeprowadzonej powyżej analizy wybranych regulacji, i to zarówno tych z zakresu prawa pracy, jak i tych z zakresu ubezpieczeń społecznych, rozwiązania stowrzone z myślą o pracownikach - nie tylko w dobie COVID-19, ale też w ogóle - wydają się w sposób wystarczający zabezpieczać tę grupę zatrudnionych przed wykluczeniem społecznym. Zdecydowanie gorsza jest w tym zakresie sytuacja osób samozatrudnionych lub tych wykonujących pracę na podstawie umów cywilnoprawnych. Należy jedynie wspomnieć - choć nie było to przedmiotem analizy - że sytuacja epidemiologiczna poza wszelkimi standardami jakiegokolwiek zabezpieczenia przed wykluczeniem społecznym pozostawiła osoby wykonujące pracę na podstawie umowy o dzieło (aktorów, muzyków, artystów). Celem Autorów było zwrócenie uwagi na poszczególne regulacje prawne, które mogłyby ewentualnie przyczynić się do wzmocnienia pozycji niepracowników na rynku pracy: wykorzystanie uniwersalizmu prawa pracy, przemodelowanie istniejących już definicji czy też zaproponowanie zupełnie nowych rozwiązań, szczególnie na gruncie ubezpieczeń społecznych. Nie można bowiem w dalszym ciągu zezwalać na 
to, aby i tak wystarczająco już trudna sytuacja kobiet na rynku pracy była uzależniona wyłącznie od formy zatrudnienia, z tendencją do wykluczania kobiet zatrudnionych na podstawie umów cywilnoprawnych (samozatrudnionych), które pozbawione są nie tylko realnej ochrony zatrudnienia, ale również należytego zabezpieczenia ze strony państwa.

Umowy cywilnoprawne mają swoje przeznaczenie. Praktyka dostarcza wystarczających dowodów, że stosowanie tego typu umów jako formy powierzenia pracy jest wątpliwe. Mimo to ustawodawca nie podejmuje żadnych konkretnych działań, aby tę (swoistą dla polskiego porządku prawnego) sytuację uregulować. Działania polegające na objęciu obowiązkiem ubezpieczenia czy ustalenia stawki godzinowej świadczą bardziej o koniunkturalnym niż paternalistycznym podejściu ustawodawcy.

\section{Bibliografia}

Baran K.W. (red.) (2018) Kodeks pracy. Komentarz, wyd. 4, Warszawa.

Baran K.W. (red.) (2020) Tarcza antykryzysowa. Szczególne regulacje w prawie pracy, prawie ubezpieczeń społecznych. Komentarz, Warszawa.

Czerniak-Swędzioł J., Mądrzycki B. (2019), Oczekiwania społeczne jako empiryczny wykładnik granic funkcji ochronnej prawa pracy, „Studia z Zakresu Prawa Pracy i Polityki Społecznej”, nr 4.

Golinowska S. (2002) Europejski model socjalny i otwarta koordynacja polityki społecznej, „Polityka Społeczna”, nr 11-12.

Jędrasik-Jankowska I. (2003) Ubezpieczenie społeczne, t. 3: Ubezpieczenie chorobowe, ubezpieczenie wypadkowe, Warszawa.

Jędrasik-Jankowska I. (2015) Niektóre regulacje prawne ubezpieczenia chorobowego, rentowego i wypadkowego a konstytucyjna zasada równości i sprawiedliwości, „Annales Universitatis Mariae Curie-Skłodowska Lublin - Polonia".

Masewicz W., Kasprowicz Ł. (2015) Ochrona pracy jako problem prawno społeczny, „Studia z Zakresu Prawa Pracy i Polityki Społecznej".

Roszewska K. (2020) Pojęcie „pracownik” w ustawie o systemie ubezpieczeń społecznych, „Radca Prawny", nr 1.

Rzetecka-Gil A. (2009) Ustawa z dnia 25 marca 1999 r. o świadczeniach pieniężnych z ubezpieczenia społecznego $w$ razie choroby i macierzyństwa. Komentarz, LEX.

Szubert W. (1980) Zarys prawa pracy, Warszawa.

ZUS (2017) Rzeczpospolita Ubezpieczonych. Historia ubezpieczeń społecznych w Polsce, https://www. zus.pl/documents/10182/1877572/Broszura+historyczna+-+Rzeczpospolita+ubezpieczonych Część1.pdf/42f37fc0-40fa-3a15-62f6-4ee5c2c6b16d (dostęp: 1 czerwca 2020).

\section{Orzecznictwo}

Postanowienie Sądu Najwyższego z dnia 29 grudnia 1998 roku, I PKN 494/98, Legalis nr 44382. Wyrok Trybunału Konstytucyjnego z dnia 6 marca 2007 roku, P 45/06, OTK-A 2007, nr 3, poz. 22. Wyrok Trybunału Konstytucyjnego z dnia 6 marca 2007 roku, P 46/06, OTK-A 2007, nr 3, poz. 22. 
Wyrok Trybunału Konstytucyjnego z dnia 16 listopada 2010 roku, P 86/2008, LEX nr 613882. Wyrok Sądu Najwyższego z dnia 27 lipca 2011 roku, II PK 20/11, LEX nr 1026630.

Wyrok Sądu Najwyższego z dnia 18 grudnia 2014 roku, II PK 50/14, Legalis nr 1185774.

Wyrok Sądu Apelacyjnego w Poznaniu z dnia 14 maja 2015 roku, III AUa 1394/14, LEX nr 1798650. Wyrok Sądu Apelacyjnego w Lublinie z dnia 27 kwietnia 2016 roku, III AUa 1023/15, Legalis nr 1460532.

Wyrok Sądu Najwyższego - Izba Pracy, Ubezpieczeń Społecznych i Spraw Publicznych z dnia 28 marca 2017 roku, II PK 15/16, Legalis nr 1617915.

\section{Akty prawa krajowego}

Konstytucja Rzeczypospolitej Polskiej z dnia 2 kwietnia 1997 roku, Dz.U. 1997, nr 78, poz. 483 z dnia 16 lipca 1997 roku.

Ustawa z dnia 23 kwietnia 1964 roku - Kodeks cywilny, Dz.U. 2020, poz. 1740 tekst jedn. z dnia 8 października 2020 roku.

Ustawa z dnia 26 czerwca 1974 roku - Kodeks pracy, Dz.U. 2020, poz. 1320 tekst jedn. z dnia 30 lipca 2020 roku.

Ustawa z dnia 23 maja 1991 roku o związkach zawodowych, Dz.U. 2019, poz. 263 tekst jedn. $\mathrm{z}$ dnia 12 lutego 2019 roku.

Ustawa z 13 października 1998 roku o systemie ubezpieczeń społecznych, Dz.U. 2020, poz. 266 tekst jedn. z dnia 19 lutego 2020 roku.

Ustawa z dnia 25 czerwca 1999 roku o świadczeniach pieniężnych z ubezpieczenia społecznego w razie choroby i macierzyństwa, Dz.U. 2020, poz. 870 tekst jedn. z dnia 15 maja 2020 roku.

Ustawa z dnia 11 kwietnia 2008 roku o zmianie ustawy o świadczeniach pieniężnych z ubezpieczenia społecznego w razie choroby i macierzyństwa, Dz.U. 2008, nr 93, poz. 582.

Ustawa z dnia 4 lutego 2011 roku o opiece nad dziećmi w wieku do lat 3, Dz.U. 2021, poz. 75 tekst jedn. $z$ dnia 13 stycznia 2021 roku.

Ustawa z dnia 2 marca 2020 roku o szczególnych rozwiązaniach związanych z zapobieganiem, przeciwdziałaniem i zwalczaniem COVID-19, innych chorób zakaźnych oraz wywołanych nimi sytuacji kryzysowych, Dz.U. 2020, poz. 1842 tekst jedn. ze zm.

Ustawa z dnia 31 marca 2020 roku o zmianie ustawy o szczególnych rozwiązaniach związanych z zapobieganiem, przeciwdziałaniem i zwalczaniem COVID-19, innych chorób zakaźnych oraz wywołanych nimi sytuacji kryzysowych oraz niektórych innych ustaw, Dz.U. 2020, poz. 568. 